\title{
Enhancement of Pitting Corrosion Resistance of Austenitic Stainless Steel Through Deposition of Amorphous/Nanocrystalline Oxy-nitrided Phases by Active Screen Plasma Treatment
}

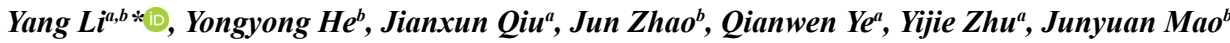 \\ ${ }^{a}$ Department of Materials Science and Engineering, Yantai University, Yantai, 264005, PR, China \\ ${ }^{b}$ State Key Laboratory of Tribology, Tsinghua University, Beijing, 100084, PR, China
}

Received: July 31, 2017; Revised: June 30, 2018; Accepted: September 22, 2018

\begin{abstract}
In this research, AISI 304 austenitic stainless steels were efficient treatment using active screen plasma oxy-nitriding technique. The modified layers were characterized by X-ray photoelectron spectroscopy, $\mathrm{X}$-ray diffraction, scanning electron microscopy, transmission electron microscopes, and atomic force microscopy. In addition, the pitting corrosion resistances of untreated and oxy-nitrided samples were analyzed by polarization method in $3.5 \mathrm{wt} . \% \mathrm{NaCl}$ solution. The results showed that a duplex-layer consisting of a deposition layer and a diffusion layer (including $\mathrm{CrN}+\alpha$ phase and nitrogen expanded austenite phase) was generated. Special concern has been given to the formation of an amorphous top layer for the deposition of nano sized oxy-nitrides. It believed that the deposition layer of oxy-nitrides formed on steel surface during active screen plasma oxy-nitriding that lead to improved corrosion resistance of AISI 304 austenitic stainless steel, so that the pitting corrosive attack can be avoided.
\end{abstract}

Keywords: Pitting corrosion, oxy-nitrided, austenitic stainless steel, XPS.

\section{Introduction}

With excellent plasticity and corrosion resistance, austenitic stainless steel can be used as surgical tool, human implant material and testing equipment for strong magnetic field ${ }^{1}$. The formation of thin passive film on steel surface can account for the resistance to general corrosion in atmosphere condition. However, the components made of austenitic stainless steel may be wear and deformation failure due to its low hardness and poor tribological properties ${ }^{2}$. In addition, pitting corrosion normally occurs at the sites of local heterogeneities as a consequence of local breakdown of adherent passive film in chloride $\left(\mathrm{Cl}^{-}\right)$environments ${ }^{3-7}$. The hardness and tribological properties of austenitic stainless steels can be improved by enriching the near-surface region using low temperature plasma nitriding ${ }^{8-12}$. However, direct current plasma nitriding (DCPN) technology, which has been used most frequently at present, is subjected to edge effect and surface $\operatorname{arcing}^{13}$. Therefore, active screen plasma nitriding (ASPN) comes as an alternative method to improve the modification of components surfaces ${ }^{14-19}$.

As a mature technique, the mechanism of nitrogen mass transfer in the ASPN process has never been finally determined. Zhao et al. ${ }^{20}$ believed that the nitrogen was mainly transferred from iron nitride particles of active screen into the matrix. S. C. Gallo and Dong ${ }^{21}$ pointed out that the mechanism of ASPN treatment may observe the model of 'sputtering-deposition- decomposition-diffusion', while A. Saeed et al..$^{22}$ believed that the 'sputtering and re-condensation' model on which the model that ASPN treatment was based. J.G. Partridge et al. ${ }^{23}$ described that it was the implantation

*e-mail: metalytu@163.com of energetic nitrogen species generated at the active screen that facilitate nitrogen mass transfer.

The relationship between the nitriding-oxidation and corrosion has been studied by some researchers. Lin et al. ${ }^{24}$ found that AISI 316 austenite stainless steel can enjoy an improved corrosion resistance by performing low temperature ASPN treatment in $0.05 \mathrm{M} \mathrm{H}_{2} \mathrm{SO}_{4}$ solution. By implementation of the pre-oxidation process before nitridation, it can lead to the formation of protective oxide layer on the surface, so as to improve the corrosion resistance of stainless steel ${ }^{25,26}$. Yoon et al. ${ }^{25}$ found that the successive implementation of pre-oxidation and nitridation led to the generation of oxide and discrete Cr-nitrided particles on steel surface. During post-oxidation process, it is very important to control the oxidation to avoid the formation of hematite $\left(\mathrm{Fe}_{2} \mathrm{O}_{3}\right)$, while to enhance formation of pure magnetite $\left(\mathrm{Fe}_{3} \mathrm{O}_{4}\right)$ which enjoys high corrosion resistance ${ }^{27}$. Parascandola et al. ${ }^{28}$ investigated that the oxygen is present near the surface in the form of a stoichiometric and laterally homogeneous oxide layer, and it acts as a barrier for diffusional transport. A sufficiently large oxygen content stops the nitrogen diffusion so that the actual oxygen uptake during the nitrogen diffusion inside the substrate should be low. There are very few researches on the analysis of micro-morphology of the oxy-nitrided phases layer and on the influence of deposition layer to steel corrosion resistance in the chloride environments ${ }^{29-32}$. Therefore, this paper aims at investigating the chemical and micro- structural features of the modified layers of treated AISI 304 austenitic stainless steels and thus revealing the electrochemical behavior of the deposition layer resulted by the implementation of active screen plasma oxy-nitrided treatment. 


\section{Experiments}

\subsection{Materials}

Coupon samples, $6 \mathrm{~mm}$ in thickness and $20 \mathrm{~mm}$ in diameter, were cut from a rolled bar of AISI 304 austenitic stainless steel, whose chemical composition is tabulated in Table 1. The rolled bar was heat-treated for $1 \mathrm{~h}$ at $1050{ }^{\circ} \mathrm{C}$ under high vacuum and finally water-quenched before testing. All samples were successively gritted with $\mathrm{SiC}$ papers in serial No. 240, 500, 1000, 1500, and 2000, and then polished into mirror surface using $3.5 \mu \mathrm{m}$ diamond powder, and finally cleaned with acetone in an ultrasonic bath.

\subsection{Surface treatment}

A LDMC-20 pulsed plasma unit was used to perform active screen plasma treatment experiments ${ }^{33,34}$. According to the ASPN setups in Fig.1, the metallic mesh, made from the 6-mm thick AISI 1020 steel plate, is connected to the cathode of the power supply. The chemical composition of the AISI 1020 steel is given in Table 1. The samples were placed in a metal screen, floating above the insulating material. Active screen plasma oxy-nitrided (ASPON) treatments were carried out under $300 \mathrm{~Pa}$ at 410,440 and $470{ }^{\circ} \mathrm{C}$ for $16 \mathrm{~h}$. The flow rates of ammonia $\left(\mathrm{NH}_{3}\right)$ and oxygen $\left(\mathrm{O}_{2}\right)$ flowing in the chamber are 480 500 sccm and 10 14 sccm, respectively.

\subsection{Potentiodynamic polarization measurement}

The corrosion potential $\left(\mathrm{E}_{\text {corr }}\right)$ and pitting potential $\left(\mathrm{E}_{p i t}\right)$ of the samples were measured in aqueous chloride solution to evaluate localized corrosion resistance of substrate and treated samples. Using a three-electrode cell consisting of a working electrode, a saturated calomel reference electrode (SCE), and a platinum rod counter electrode, the electrochemical tests were conducted in 3.5 wt.\% $\mathrm{NaCl}$ solution using CHI-600E electrochemical working station. It is worth noting that all corrosion tests in this paper were carried out at indoor temperature.

\subsection{Characterization methods}

The phase structures of the untreated and treated samples were characterized using X-ray diffractometer (Bruker D8ADVANCE) with $\mathrm{Cu} \mathrm{K} \alpha$ radiation $(\lambda=1.5406 \AA)$. Based on FEI Quanta 200 FEG scanning electron microscopy (SEM) equipped with energy dispersive X-ray spectroscopy (EDS), the surface topographies of the polished and treated sample were analyzed. In atmosphere condition, the evolution of surface morphology was investigated using an atomic force microscope (AFM) in ultra-light tapping mode. The AFM

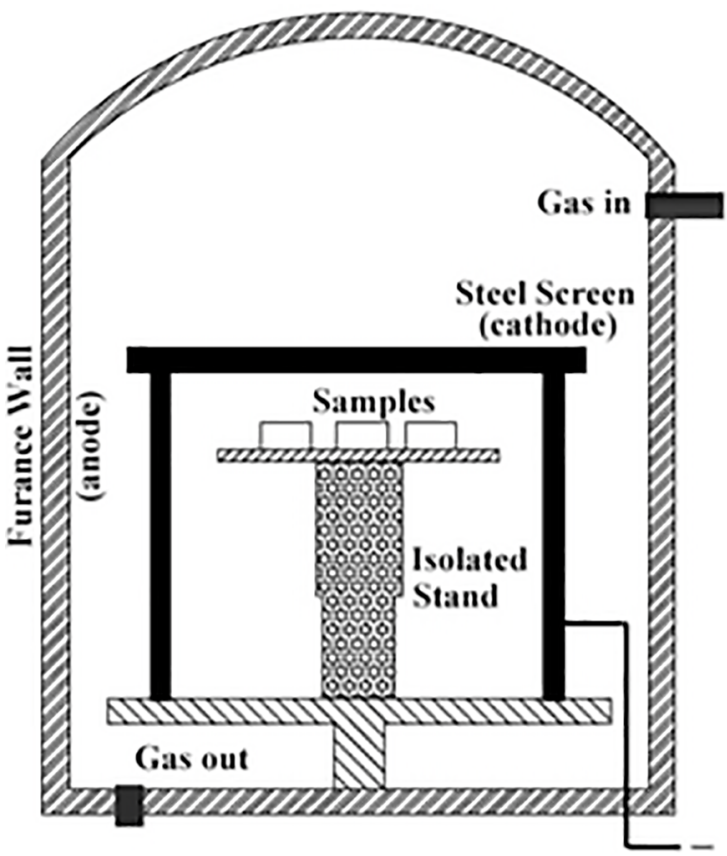

Figure 1. Schematic diagram of the main components of the active screen plasma oxy-nitriding

technique allows for the measurement of the nano-roughness $R_{\mathrm{a}}$ value, which is the arithmetic mean surface roughness. A JEOL-2100 transmission electron microscope (TEM) was adopted to study the microstructural characteristics of the treated layer. Chemical characterization was conducted using a V.G. Escalab250 spectrometer based on X-ray photoelectron spectroscopy (XPS). The XPS data were collected using monochromatic $\mathrm{Al} \mathrm{K} \alpha$ radiation at $1486.6 \mathrm{eV}$, which mainly covered circular irradiated area with diameter of $500 \mu \mathrm{m}$. XPS spectra were obtained using an Ar ion beam to study the chemical composition at different depths. Based on the binding energy of the $\mathrm{C}_{1 \mathrm{~s}}$ neutral carbon peak at $284.6 \mathrm{eV}$ as reference value, the measured binding energies were corrected.

\section{Results and Discussion}

The XRD spectra of untreated and treated samples are shown in Fig. 2. In the case of untreated sample, the diffraction spectra show $\gamma($ austenite $)$ and $\alpha$ (martensite) peaks. The latter phase was formed during the preparation of the samples ${ }^{35}$. For the sample oxy-nitrided for the $410^{\circ} \mathrm{C}$, two new face centered cubic (fcc) peaks were presented. Both peaks appeared at lower angles when compared to the austenite $\gamma$ phase from the substrate. These peaks have been associated with a metastable phase called 'expanded austenite' and

Table 1. Chemical compositions of the AISI 304 and low alloy steel (wt.\%)

\begin{tabular}{lcccccc}
\hline & $\mathrm{C}$ & $\mathrm{Cr}$ & $\mathrm{Ni}$ & $\mathrm{Mn}$ & $\mathrm{Si}$ & $\mathrm{Fe}$ \\
\hline AISI 304 & $<0.08$ & $18.0-19.0$ & $8.40-9.0$ & 2.00 & $<0.80$ & In balance \\
AISI 1020 & $0.17-0.23$ & $<0.25$ & $<0.25$ & $0.35-0.60$ & 0.25 & In balance \\
\hline
\end{tabular}




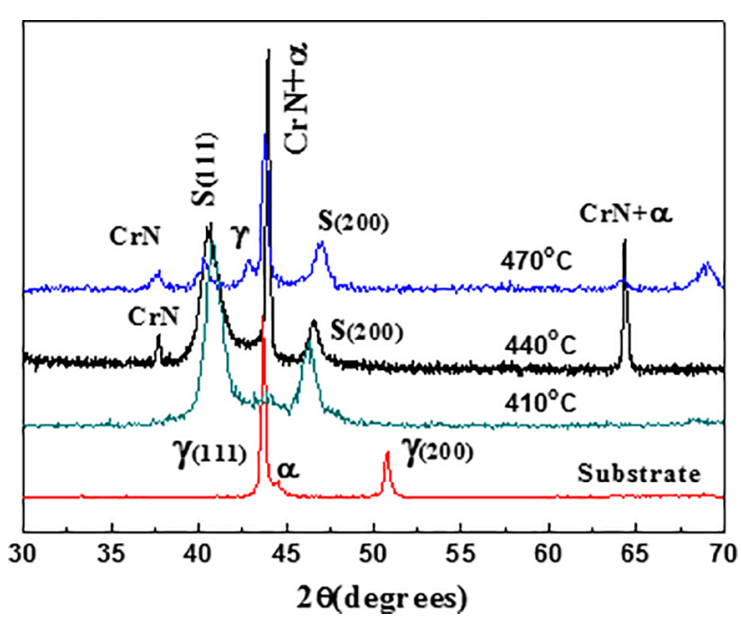

Figure 2 . XRD patterns of the untreated and oxy-nitrided samples.

designated by S (111) and S (200) phases. The lattice of austenite was expanded due to the nitrogen atom dissolved in the surface region of an austenitic stainless steel ${ }^{36}$. Fig. 3 is the SEM of the cross-section of the samples oxy-nitrided at different temperatures. For the samples nitrided at $410^{\circ} \mathrm{C}$ and $440{ }^{\circ} \mathrm{C}$, it could be seen that the nitrided layers are resistant to the etching reagent. The thickness of the nitrided layers were measured to be about $2.6 \mu \mathrm{m}, 5.2 \mu \mathrm{m}$ for the samples nitrided at $410{ }^{\circ} \mathrm{C}$ and $440{ }^{\circ} \mathrm{C}$, respectively. When the nitriding treatments at $440{ }^{\circ} \mathrm{C}$, together with S-phase diffraction peaks, $\mathrm{CrN}$ and $\alpha$-Fe diffraction peaks are clearly detected (Fig.2). In particular, there may be the $\gamma^{\prime}-\mathrm{Fe}_{4} \mathrm{~N}$ phase in the nitrided surface. It may be related to the deposition effect during ASPON treatment. This phase appears to be unique to ASPON and could not be found in a DCPN nitrided surface $^{37}$. However, the dark spots were not observed in the nitrided $440^{\circ} \mathrm{C}$ sample (Fig. $3 \mathrm{~b}$ ). Xu et al. ${ }^{38}$ suggested that the $\mathrm{S}$ phase consists of $\mathrm{Fe}_{4} \mathrm{~N}$ with $\mathrm{CrN}$ clustering, but without precipitating compound of $\mathrm{CrN}$ when nitriding at a low temperature. Some dark spots become visible in the nitrided $470{ }^{\circ} \mathrm{C}$ sample (Fig.3c), and the thickness goes up to $6.5 \mu \mathrm{m}$. The nitrided layer thickness increases with the process temperatures. Increased the treatment temperature $\left(>450^{\circ} \mathrm{C}\right)$ resulted to an increase in the intensity of the $\mathrm{CrN}$ and $\alpha$-Fe phases and a reduction of the $\mathrm{S}$ phases. It can be shown that the formation of these dark phases is associated with the precipitation of $\mathrm{CrN}$ which deteriorates the corrosion resistance of the stainless steel.

Fig. 4 shows typical surface morphology and EDS microanalysis of the substrate and treated samples. According to Fig. 4 a, polishing scratches can be observed on the surface of the untreated samples, while particle deposition phenomenon can be observed on the surface of the treated sample (Fig.4b). Based on the EDS analysis of surfaces of the treated samples, the presence of large amounts of nitrogen and small amounts of oxygen can be determined. The AFM results (Fig. 5) are well consistent with the SEM results (Fig.

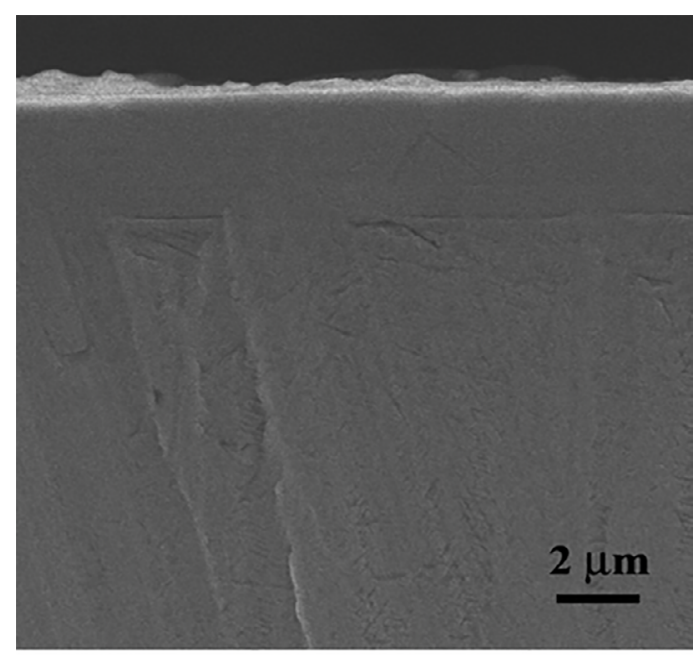

(a) $410^{\circ} \mathrm{C}$

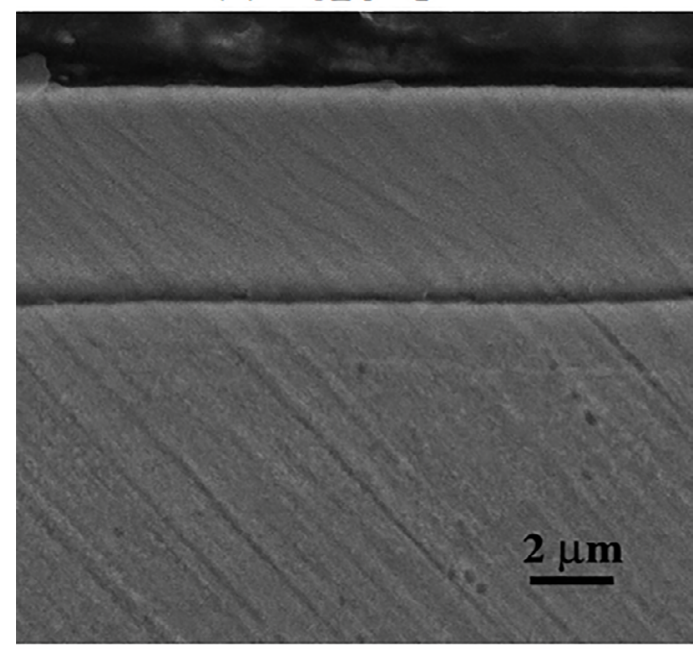

(b) $440^{\circ} \mathrm{C}$

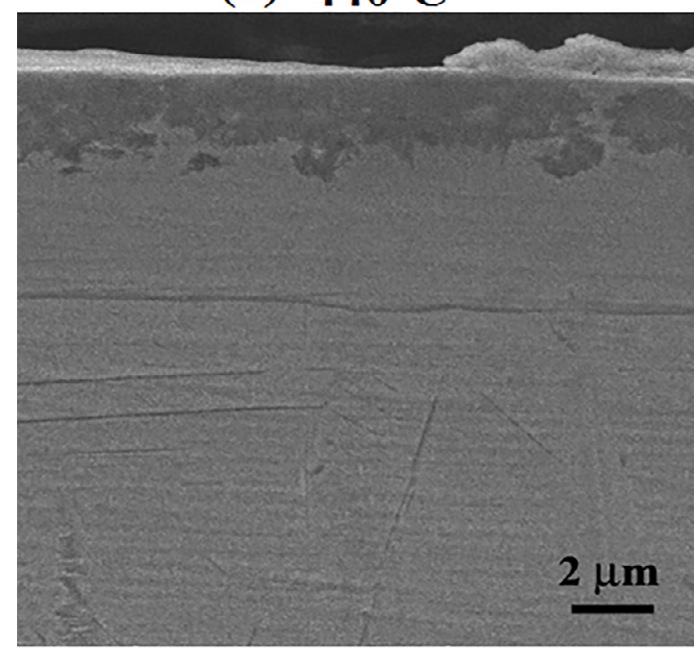

(c) $470^{\circ} \mathrm{C}$

Figure 3 . SEM cross-sectional images of the treated samples. 


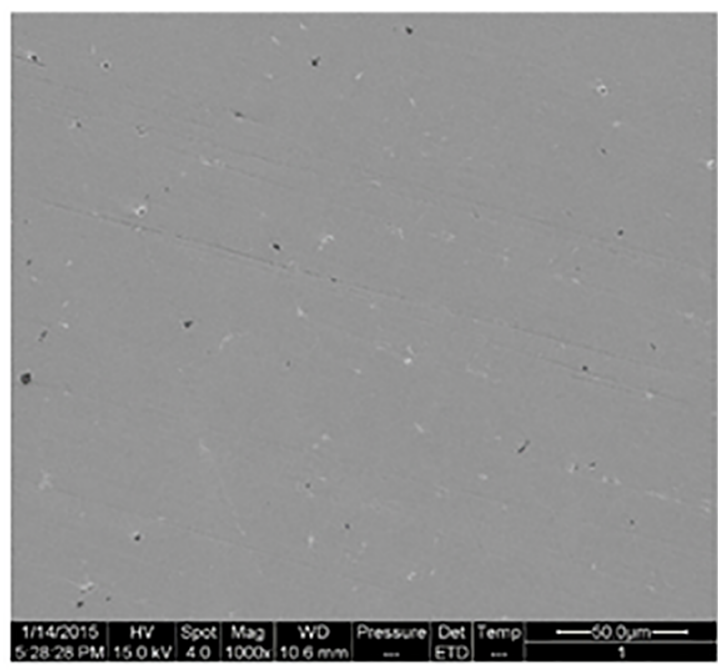

(a) substrate

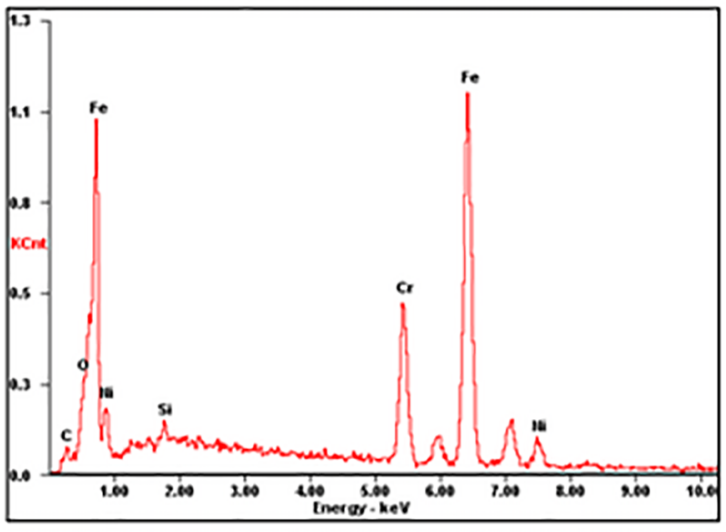

(c) substrate

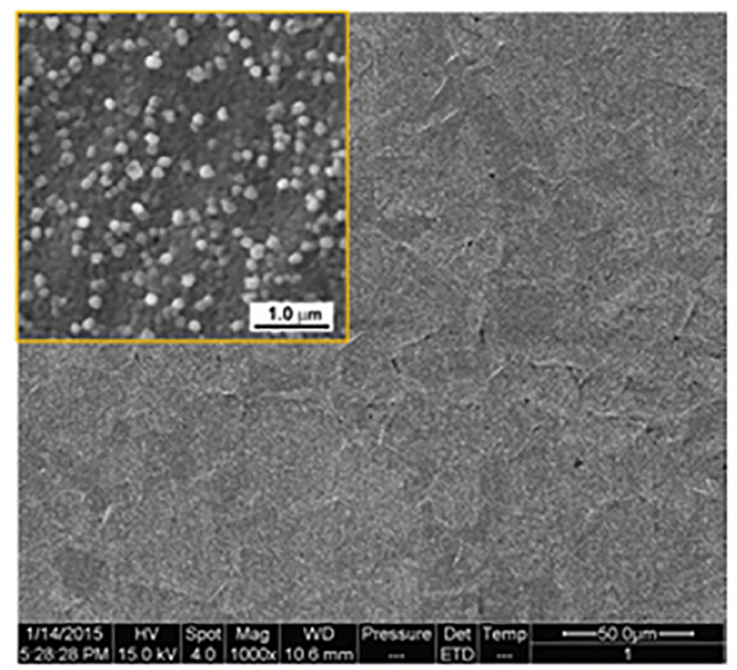

(b) $440^{\circ} \mathrm{C}$ treated samples

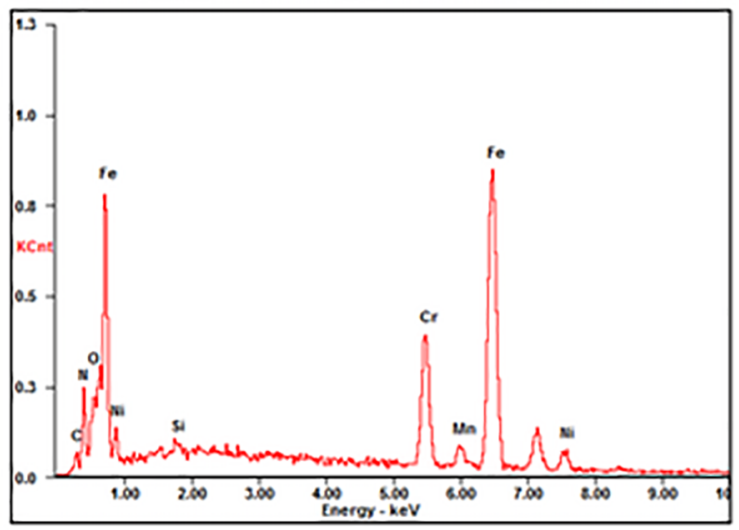

(d) $440^{\circ} \mathrm{C}$ treated samples

Figure 4. SEM image from substrate (a) and the $440^{\circ} \mathrm{C}$ treated samples(b). EDS microanalysis of the substrate (c) and the treated surface (d).

4). The AFM morphology of cc is shown in Fig. 5a and b. It can observe polishing characteristics on the surface of untreated samples which reaching surface roughness $\left(R_{\mathrm{a}}\right)$ of about $1.5 \mathrm{~nm}$. The AFM surface micrographs of the treated samples are shown in Fig. 5c and d, from which it cancan observe a compact layer where oxy-nitrided particles in sizes of 80-160nm are arranged homogeneously, and no defects can be seen on the surface of treated sample. According to the AFM micrographs, the mean surface roughness $\left(R_{\mathrm{a}}\right)$ is $23.2 \mathrm{~nm}$, which is much higher than roughness of the original sample. The deposition of a nano/micro structured layer on the treated sample are confirmed by above observations, which is different from previous studies ${ }^{21,39,40}$. When using DCPN technology, nitrided surface is featured by grain boundary and intercrystallite slip. Based on the thickness of the nitrided layer which was obtained from the trappingdetrapping diffusion model, C. Templier et al. ${ }^{39}$ compared the swellings between $<001>$ and $<111>$ oriented grains and found the basis of plastic strain. J.C. Stinville et al. ${ }^{41}$ found that, slip bands that correspond to $\{111\}$ planes sliding gradually developed with the extending of nitriding time. With regard to ASPN technology, surface nitriding is basically a deposition mechanism. Sh. Ahangarani et al. ${ }^{42}$ found that the ASPN surface is mainly composed hexagonal particles in regular distribution and well-defined boundaries. S. Corujeira Gallo et al. ${ }^{21}$ found that that the grey surfaces were covered with fine deposited particles which could not be found in the black areas.

Fig.6 shows the variation of concentration of $\mathrm{N}, \mathrm{O}$, $\mathrm{Fe}, \mathrm{Cr}$ and $\mathrm{Ni}$ as a function of the sputtering depth. The concentration of $\mathrm{N}$ remains merely changed within the range of $18 \sim 20$ at. $\%$ at the end of depth profile analysis. The content of $\mathrm{O}$ on the surface is 47 at. \%, which is then quickly decreased to approximately 4 at.\%. Element $\mathrm{O}$ may stem from the vacuum wall. Within the $80 \mathrm{~nm}$ of sputtering depth of the treated sample, the concentrations of $\mathrm{Cr}$ and $\mathrm{Ni}$ are low, which are 2.0 at. $\%$ and 0.5 at. \%, respectively. Such low $\mathrm{Cr}$ concentrations on the surface is due to that $\mathrm{Cr}$ element mainly comes from the particles sputtered from the AISI 1020 steel screen. 


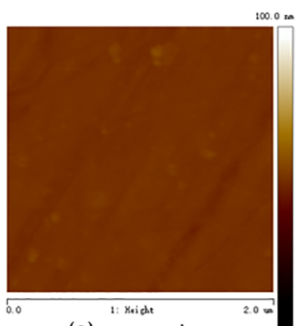

(a) untreated

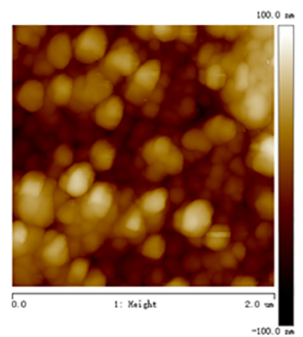

(c) oxy-nitrided

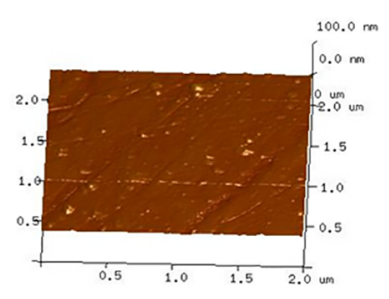

(b) untreated

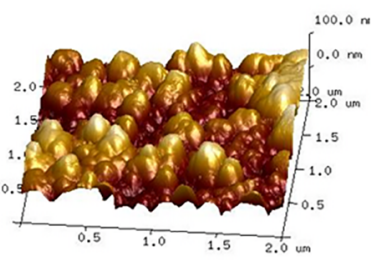

(d) oxy-nitrided
Figure 5 . AFM images of untreated $(a, b)$ and the $440{ }^{\circ} \mathrm{C}$ oxynitrided (c, d) samples.

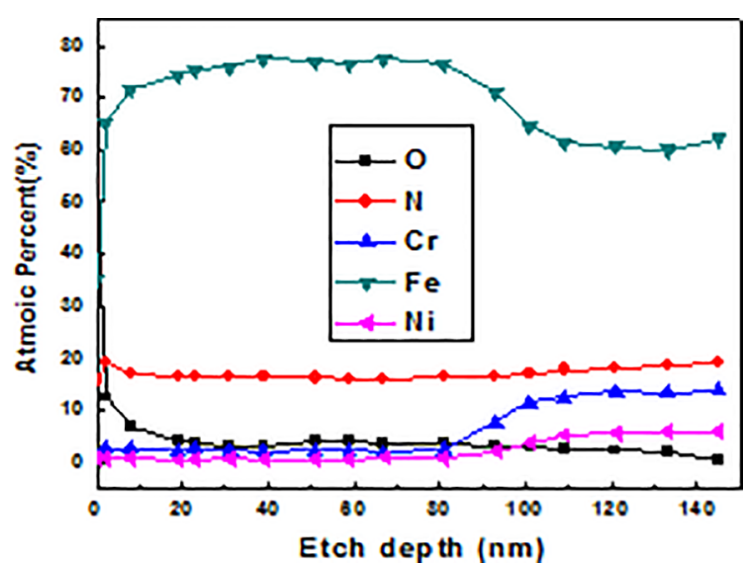

Figure 6. The variation of atomic concentrations of $\mathrm{N}, \mathrm{O}, \mathrm{Fe}$, $\mathrm{Cr}$ and $\mathrm{Ni}$ elements with depth of the $440^{\circ} \mathrm{C}$ oxy-nitrided sample.

Fig. 7a-d respectively show the of photoelectron regions $\mathrm{Fe} 2 \mathrm{p}_{3 / 2}, \mathrm{Cr} 2 \mathrm{p}_{3 / 2}, \mathrm{~N} 1 \mathrm{~s}$ and $\mathrm{O} 1 \mathrm{~s}$ on the modified layer. It can be known that $\mathrm{Fe} 2 \mathrm{p}_{3 / 2}$ peak mainly consists of five peaks centered at $706.4 \mathrm{eV}$ (metallic Fe), 707.9 and $708.8 \mathrm{eV}$ (iron oxides), and 706.9 and $707.3 \mathrm{eV}$ (iron nitrides) according to the deconvolution analysis. According to the XPS spectrum of Fe $2 p_{3 / 2}$, it can be known that iron is mainly in nitridation and oxidation states ${ }^{43}$. There is a peak at $574.3 \mathrm{eV}$ which corresponds to the metallic species of $\mathrm{Cr}$, and a peak at 576.4 $\mathrm{eV}$ which corresponds to the formation of $\mathrm{Cr}_{2} \mathrm{O}_{3}{ }^{44}$. The center of the $\mathrm{Cr} 2 \mathrm{p}_{3 / 2}$ peak is located at the binding energy which is assigned to the formation of chromium nitrides ${ }^{45}$. The $\mathrm{N} 1 \mathrm{~s}$ spectrum is composed of four peaks, including two strong ones at 397.5 and $398.0 \mathrm{eV}$ corresponding to iron nitrides, a weak one at $397.1 \mathrm{eV}$ corresponding to chromium nitrides, and one at $398.5 \mathrm{eV}$ associated with an oxygen group.
According to the deconvolution of the $\mathrm{O}$ 1s signal peak, it can observe three peaks, including a weak one at $532.0 \mathrm{eV}$ associated with nitrogen group, and two strong ones at 530.1 and $531.2 \mathrm{eV}$ corresponding to chromium oxides and iron oxides, respectively. According to XPS results, the deposition layer mainly consists of oxy-nitrides of iron and element $\mathrm{Cr}$.

Fig. 8 shows TEM microstructure and selected area diffraction (SAD) of the modified layer. As shown in Fig. 8a, it can observe a duplex modified layer consisting of a deposition layer and an underneath high-nitrogen diffusion layer. The thickness of top deposition layer is approximately $100 \mathrm{~nm}$, while the SAD pattern is in an amorphous structure which can be accounted by the high content of oxygen. P.Wilhartitz et al. ${ }^{46}$ found that oxygen in nitrided layer played a role in stabilizing the fine crystalline structure. The XPS investigations confirmed that $\mathrm{O}-\mathrm{N}$ bonding could be detected in this layer (Fig.7). The deposition top layer is probably composed of amorphous/nanocrystalline oxy-nitrides of iron.

According to the TEM micrograph of the diffusion layer, the outer region corresponds to corresponding SAD patterns of the $\mathrm{CrN}+\alpha-\mathrm{Fe}$ phases (Fig.8c), while inner region corresponds the S-phase (Fig.8d). Detailed characterization showed that the S-phase of the inner region is in a face centered cubic structure with severe dislocations. However, due to effect of longtime nitriding treatment, the migration energy of substitutional atom is large enough, which can quickly realize the equilibrium. As the bond between chromium and nitrogen is stronger than that between other substitutional atoms and nitrogen, chromium nitride can nucleate and grow $^{8}$. The nitrogen solid solution in austenite S-phase can be decomposed into $\mathrm{CrN}$ and $\alpha$-Fe in the outer region given that the treatment time is long enough. $\mathrm{Li}^{47}$ found that the thermodynamically metastable $\mathrm{S}$ phase can be transformed into the stable $\mathrm{CrN}$ and $\gamma_{\mathrm{N}}$ after subjected to thermal annealing treatment at appropriate temperature for a certain period of time. According to SAD pattern, it can be known that this region is composed of $\mathrm{CrN}$ and $\alpha-\mathrm{Fe}$, which is in accordance with the XRD result (Fig.3).

The potentiodynamic polarization curves of the untreated and treated samples in $3.5 \mathrm{wt} . \% \mathrm{NaCl}$ solution obtained by Tafel extrapolation method are shown in Fig.9. It can be seen that the untreated sample has an evident passivation region, and the corrosion potential is $-0.32 \mathrm{~V}_{\text {(SCE) }}$, and the current density rapidly increased at a potential of around $0.22 \mathrm{~V}_{(\mathrm{SCE})^{.}}$It is well known that this sudden increase in current density is caused by the break-through of the passive layer on stainless steel and pitting corrosion initiates in the chloride ion containing environment.

The corrosion behavior of the oxy-nitrided samples is largely related to their oxy-nitrided temperatures. For the $410^{\circ} \mathrm{C}$ oxy-nitrided sample, the corrosion potential is shifted to a higher value $\left(-0.20 \mathrm{~V}_{(\mathrm{SCE})}\right)$, and the polarization curve exhibit very low anodic current density. This indicates that the nitrided layer are able to protect the substrate, providing a 


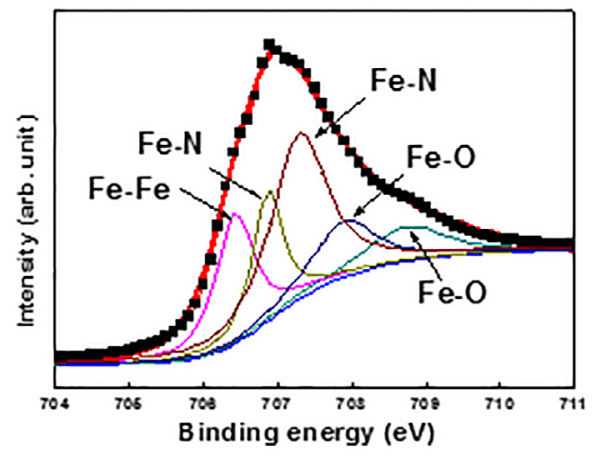

(a) $\mathrm{Fe} 2 p_{3 / 2}$

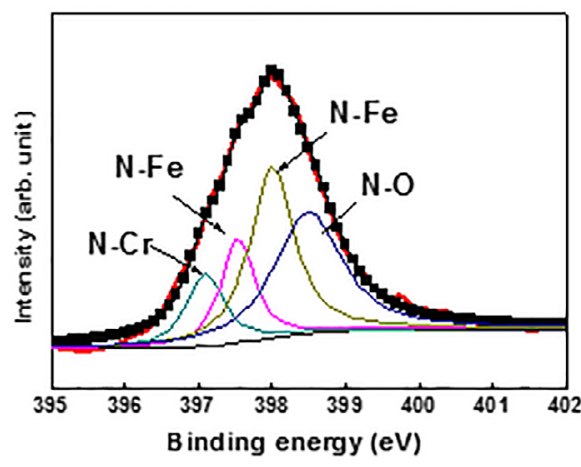

(c) $\mathrm{O} 1 \mathrm{~s}$

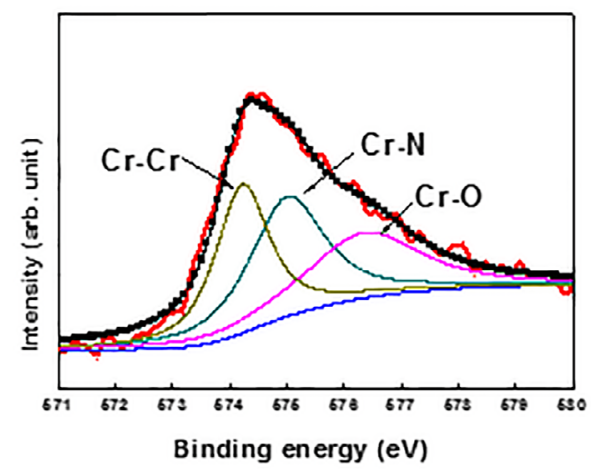

(b) $\operatorname{Cr} 2 p_{3 / 2}$

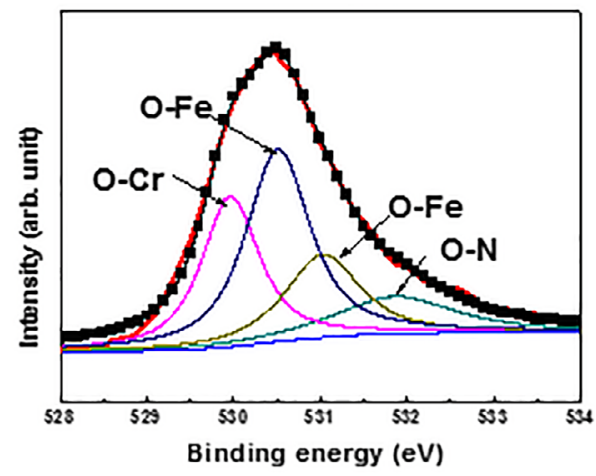

(d) $\mathrm{N} 1 \mathrm{~s}$

Figure 7. XPS spectra of $\mathrm{Fe} 2 p_{3 / 2}$ (a), $\mathrm{Cr} 2 p_{3 / 2}$ (b), $\mathrm{O} 1 \mathrm{~s}$ (c) and $\mathrm{N} 1 \mathrm{~s}$ (d) level obtained surface of the $440^{\circ} \mathrm{C}$ oxy-nitrided sample after a sputtering depth $2 \mathrm{~nm}$.

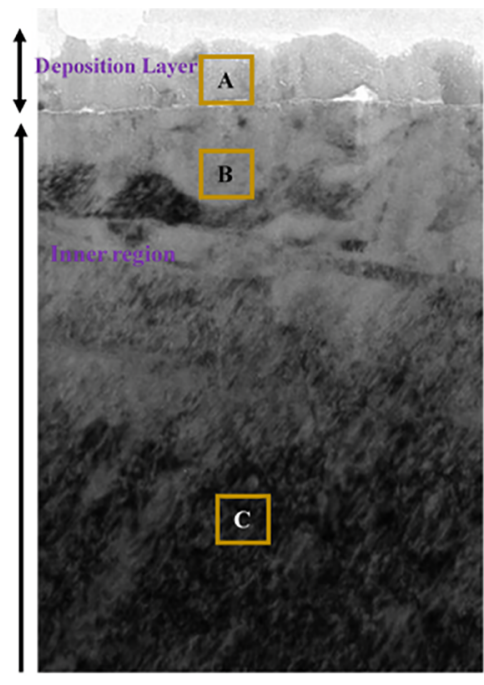

(a) Across-sectional bright field TEM micrograph
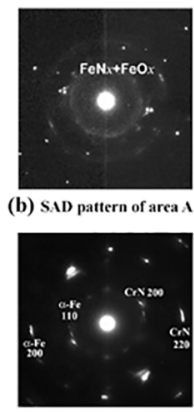

(c) SAD pattern of area B

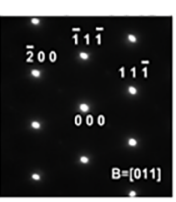

(d) SAD pattern of area C

Figure 8. Across-sectional bright field TEM micrograph and selected area electron diffraction (SAD) pattern from the near surface of the $440^{\circ} \mathrm{C}$ oxy-nitrided sample.

good barrier against localized attack at low potential. However, the anodic current density rapidly raised with the potential $\left(>0.23 \mathrm{~V}_{(\mathrm{SCE})}\right)$, This suggests that the $\mathrm{S}$ phases layer is too

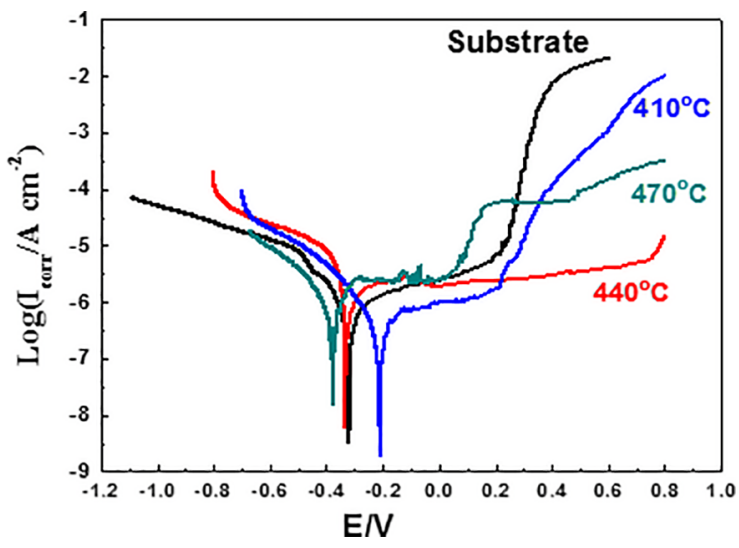

Figure 9 . Potentiodynamic polarization curves of untreated and treated samples in $3.5 \% \mathrm{NaCl}$ water solution.

thin to protect the surface against chloride ion attack. While the treatment temperature is further increased, the corrosion potential and corrosion resistance are decreased. It can be seen that the corrosion potential is decreased from $-0.32 \mathrm{~V}$ (SCE) for the untreated specimen to $-0.33 \mathrm{~V}_{\text {(SCE) }},-0.39 \mathrm{~V}_{\text {(SCE) }}$ for the nitrided $440{ }^{\circ} \mathrm{C}, 470{ }^{\circ} \mathrm{C}$ specimens, respectively. The shift of corrosion potential could be related to the thickness of the nitrided layer and the mixed phase structures $(\mathrm{CrN}$ precipitates). For the $440{ }^{\circ} \mathrm{C}$ oxy-nitrided sample, the stable 
and wide passivation region is resulted from the anodic polarization of the treated surface. In addition, corrosion current density and corrosion rate of treated sample are lower than those of untreated sample. It also found that the $470{ }^{\circ} \mathrm{C}$ oxy-nitrided sample show some deterioration in corrosion resistance compared with the $440{ }^{\circ} \mathrm{C}$ oxy-nitrided sample, but better than that of the untreated substrate. It can conclude that the treated sample have high pitting corrosion resistance as compared the untreated samples.

Fig.10shows the SEM micrographs and EDX spectra of the untreated and oxy-nitrided samples after polarisation measurement in $3.5 \mathrm{wt} \% \mathrm{NaCl}$ solution. Looking in the magnified image of pit in Fig. 10a, it can be seen that the atomic percent of chlorine is 0.87 wt.\% (Fig. 10c), which accounts for the generation of pitting corrosion. For the untreated stainless steel, its corrosion resistance is mainly determined by a passive chromium oxide film on the surface. Such thin passive film may protect the material in environment with low and medium corrosion strength. However, its protective

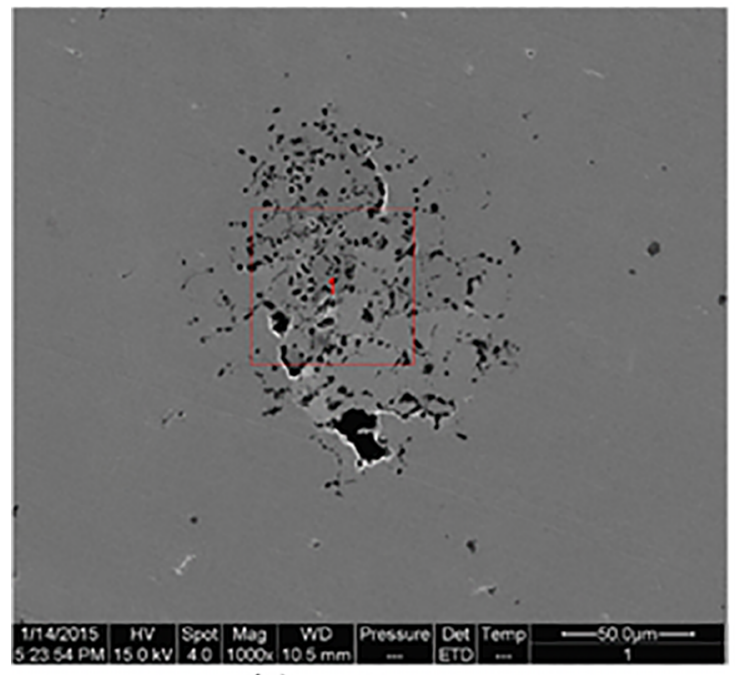

(a) substrate

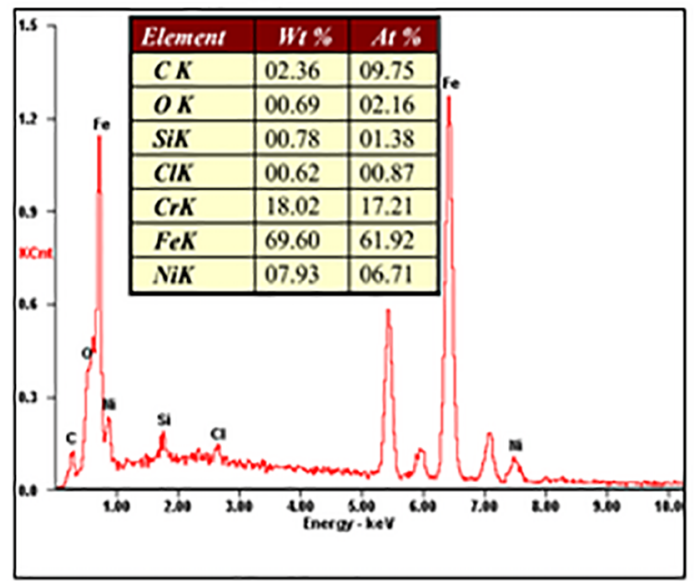

(c) substrate capability is very limited during the polarisation corrosion test in 3.5wt.\% $\mathrm{NaCl}$ solution. As shown in Fig.10b, the $440^{\circ} \mathrm{C}$ oxy-nitrided sample exhibited a homogenous surface appearance with no damages. Escalada et $\mathrm{al}^{48,49}$ found that for suitable treatment conditions, the pitting corrosion can be suppressed even without oxygen addition. A plausible theory suggested that nitrogen in stainless steel will dissolve during corrosion process and consume the acid in pit by a reaction of $\left(\mathrm{N}+4 \mathrm{H}^{+}+3 \mathrm{e}^{-} \rightarrow \mathrm{NH}_{4}^{+}\right)^{50,51}$. This causes a local neutralising effect in the acidic pits on the corrosion surface, leading to a decreased growth rate of the pit. Stefaniszyn et al. ${ }^{29}$ proposed that nitrided layers consisting of nitrogenexpanded austenite with a thin surface layer of $\mathrm{Cr}_{2} \mathrm{O}_{3}$ zone can be produced due to the implementation of anti-corrosion treatment. It believed that the deposition layer of oxy-nitrides formed on steel surface during ASPON treatment that lead to improved corrosion resistance of austenitic stainless steel, so that the pitting corrosive attack can be avoided.

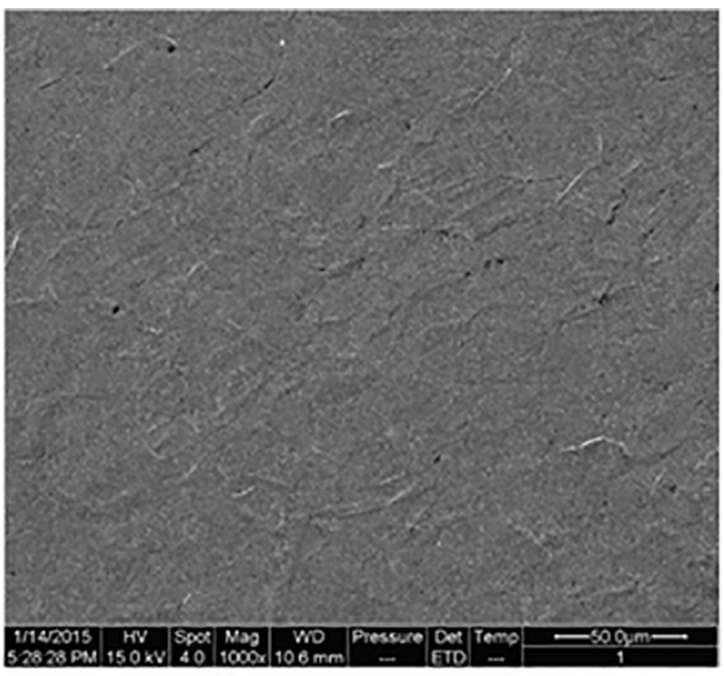

(b) treated sample

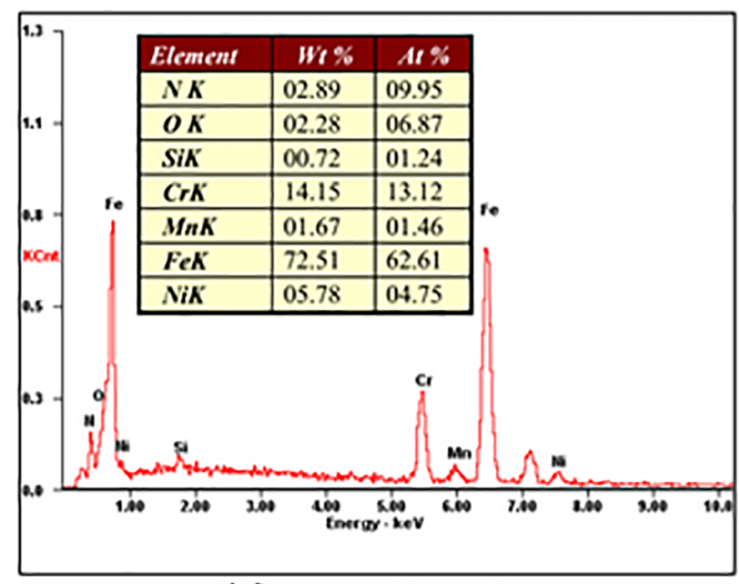

(d) treated surface

Figure 10. SEM surface micrographs of the substrate(a) and the $440^{\circ} \mathrm{C}$ treated sample(b) after polarisation in $3.5 \% \mathrm{NaCl}$ water solution; EDS microanalysis of the substrate (c) and the treated surface (d) after polarisation. 
Some particles almost completely disappear from the corrosion surface of treated sample (Fig. 10b). The AFM investigation results of treated surfaces after the polarization measurement (Fig. 11) are in line with the SEM observation results (Fig. 10b). Some large particles with mean diameter of $200 \sim 400 \mathrm{~nm}$ can be observed on the corrosion surface. It was caused by the dissolution of majority of particles on the surface during polarization test. According to the dissolution behavior of the anodic surface, it can find that oxygen and nitrogen in the passive state play a beneficial role in leading to the initial acceleration of the anodic dissolution which provides large number of passive species ${ }^{52}$. After ASP oxy-nitrided treatment, oxy-nitrides containing amorphous/ nanocrystalline top layer were generated, leading to an enhancement of pitting corrosion resistance.

\section{Conclusion}

The ASP oxy-nitrided treatment was conducted at 440 ${ }^{\circ} \mathrm{C}$ for $16 \mathrm{~h}$, resulting in a duplex surface nitrided layer structure consisting of a deposition layer and an underneath high-nitrogen diffusion layer. The deposition method introduced $100 \mathrm{~nm}$ thick amorphous/nanocrystalline top layer consisting of nano structured oxy-nitrides of iron. In the diffusion layer, it can observe at inner region a single distorted fcc structure S phase, which can be decomposed into $\mathrm{CrN}$ and $\alpha-\mathrm{Fe}$ at the outer region after keeping ASPON treatment for long enough.

Through conducting corrosion test in 3.5 wt. $\% \mathrm{NaCl}$ solution, it can find that the treated sample enjoyed higher pitting corrosion resistance than the untreated substrate did, which was mainly due to the formation of oxy-nitrides containing amorphous layer according to TEM and XPS analyses. Anodic behaviors of treated samples showed that the oxygen and nitrogen in the passive state played a beneficial role for the initial acceleration of anodic dissolution which provided larger amounts of passive species. Further researches are needed to verify the detailed mechanisms.

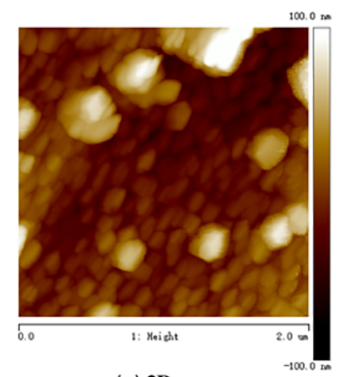

(a) 2D

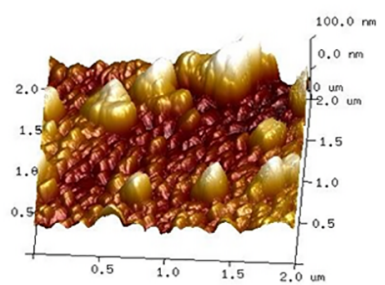

(b) 3D
Figure 11 . 2D(a) and $3 \mathrm{D}(\mathrm{b})$ topographic AFM images of the corroded surfaces of the $440^{\circ} \mathrm{C}$ treated sample.

\section{Acknowledgments}

The project was supported by the National Key Basic Research Program of China (973) (2014CB046404), the Shandong Provincial Natural Science Foundation, China (ZR2018MEE016), and the Shandong Provincial Natural Science Foundation, China (ZR201709210372), and National Natural Science Foundation of China (51301149).

\section{References}

1. Lo KH, Shek CH, Lai JKL. Recent developments in stainless steels. Materials Science and Engineering: R: Reports. 2009;65(4-6):39-104.

2. Sun Y, Haruman E. Tribocorrosion behaviour of low temperature plasma carburised 316L stainless steel in $0.5 \mathrm{M} \mathrm{NaCl}$ solution. Corrosion Science. 2011;53(12):4131-4140.

3. Zheng SJ, Wang YJ, Zhang B, Zhu YL, Liu C, Hu P, et al. Identification of $\mathrm{MnCr}_{2} \mathrm{O}_{4}$ nano-octahedron in catalysing pitting corrosion of austenitic stainless steels. Acta Materialia. 2010;58(15):5070-5085.

4. Karimzadeh N, Moghaddam EG, Mirjani M, Raeissi K. The effect of gas mixture of post-oxidation on structure and corrosion behavior of plasma nitrided AISI 316 stainless steel. Applied Surface Science. 2013;283:584-589.

5. Li Y, Wang Z, Wang L. Surface properties of nitrided layer on AISI 316L austenitic stainless steel produced by high temperature plasma nitriding in short time. Applied Surface Science. 2014;298:243-250.

6. Escalada L, Lutz J, Brühl SP, Fazio M, Márquez A, Mändl S, et al. Microstructure and corrosion behavior of AISI 316L duplex treated by means of ion nitriding and plasma based ion implantation and deposition. Surface and Coatings Technology. 2013;223:41-46.

7. Fossati A, Borgioli F, Galvanetto E, Bacci T. Corrosion resistance properties of glow-discharge nitrided AISI 316L austenitic stainless steel in $\mathrm{NaCl}$ solutions. Corrosion Science. 2006;48(6):1513-1527

8. Dong H. S phase surface engineering of $\mathrm{Fe}-\mathrm{Cr}, \mathrm{Co}-\mathrm{Cr}$ and $\mathrm{N}-\mathrm{Cr}$ alloys. International Materials Reviews. 2010;55(2):65-98.

9. Campos M, de Souza SD, Martinez LG, Olzon-Dionysio M. Study of expanded austenite formed in plasma nitrided AISI 316L samples, using synchrotron radiation diffraction. Materials Research. 2014;17(5):1302-1308.

10. Hashemi B, Rezaee Yazdi M, Azar V. The wear and corrosion resistance of shot peened-nitrided $316 \mathrm{~L}$ austenitic stainless steel. Materials \& Design. 2011;32(6):3287-3292.

11. dos Reis RF, Villanova RL, Costa KD, Durante GC. Nitrogen Surface Enrichment of Austenitic Stainless Steel ISO 5832-1: SHTPN vs Low-temperature Plasma Nitriding. Materials Research. 2015;18(3):575-580. 
12. Luo Q, Oluwafemi O, Kitchen M, Yang S. Tribological properties and wear mechanisms of DC pulse plasma nitrided austenitic stainless steel in dry reciprocating sliding tests. Wear. 2017;376377(Pt B):1640-1651.

13. Olzon-Dionysio M, Campos M, Kapp M, de Souza S, de Souza SD. Influences of plasma nitriding edge effect on properties of 316 L stainless steel. Surface and Coatings Technology. 2010;204(21-22):3623-3628.

14. Gallo SC, Dong H. Study of active screen plasma processing conditions for carburising and nitriding austenitic stainless steel. Surface and Coatings Technology. 2009;203(24):3669-3675.

15. Alves C Jr, de Araújo FO, Ribeiro KJB, da Costa JAP, Sousa RRM, de Sousa RS. Use of cathodic cage in plasma nitriding. Surface and Coatings Technology. 2006;201(6):2450-2454.

16. Li Y, He Y, Xiu JJ, Wang W, Zhu YJ, Hu B. Wear and corrosion properties of AISI 420 martensitic stainless steel treated by active screen plasma nitriding. Surface and Coatings Technology. 2017;329:184-192.

17. Espitia LA, Dong H, Li XY, Pinedo CE, Tschiptschin AP. Scratch test of active screen low temperature plasma nitrided AISI 410 martensitic stainless steel. Wear. 2017;376-377(Pt A):30-36.

18. Naeem M, Zaka-ul-Islam M, Shafiq M, Bashir MI, DíazGuillén JC, Zakaullah M. Influence of cathodic cage diameter on mechanical properties of plasma nitrided AISI 304 steel. Surface and Coatings Technology. 2017;309:738-748.

19. Kurelo BCES, de Souza GB, da Silva SLR, Daudt NF, Alves C Jr., Torres RD, et al. Tribo-mechanical features of nitride coatings and diffusion layers produced by cathodic cage technique on martensitic and supermartensitic stainless steels. Surface and Coatings Technology. 2015;275:41-50.

20. Zhao C, Li CX, Dong H, Bell T. Study on the active screen plasma nitriding and its nitriding mechanism. Surface and Coatings Technology. 2006;201(6):2320-2325.

21. Gallo SC, Dong H. New insights into the mechanism of lowtemperature active-screen plasma nitriding of austenitic stainless steel. Scripta Materialia. 2012;67(1):89-91.

22. Saeed A, Khan AW, Jan F, Abrar M, Khalid M, Zakaullah M. Validity of "sputtering and re-condensation" model in active screen cage plasma nitriding process. Applied Surface Science. 2013;273:173-178.

23. Hubbard P, Partridge JG, Doyle ED, McCulloch DG, Taylor $\mathrm{MB}$, Dowey SJ. Investigation of nitrogen mass transfer within an industrial plasma nitriding system I: The role of surface deposits. Surface and Coatings Technology. 2010;204(8):1145-1150.

24. Lin K, Li X, Sun Y, Luo X, Dong H. Active screen plasma nitriding of 316 stainless steel for the application of bipolar plates in proton exchange membrane fuel cells. International Journal of Hydrogen Energy. 2014;39(36):21470-21479.

25. Lee SH, Yang TH, Hyun SH, Yoon YS. Corrosion behavior of pre-oxidized and thermally nitrided stainless steel for polymer electrolyte membrane fuel cell bipolar plates. Corrosion Science. 2012;58:79-85.
26. Brady MP, Wang H, Turner JA, Meyer HM III, More KL, Tortorelli PF, et al. Pre-oxidized and nitrided stainless steel alloy foil for proton exchange membrane fuel cell bipolar plates: Part 1. Corrosion, interfacial contact resistance, and surface structure. Journal of Power Sources. 2010;195(17):5610-5618.

27. Mandkarian N, Mahboubi F. Effect of gas mixture of plasma post-oxidation on corrosion properties of plasma nitrocarburised AISI 4130 steel. Vacuum. 2009;83(7):1036-1042.

28. Parascandola S, Kruse O, Möller W. The interplay of sputtering and oxidation during plasma diffusion treatment. Applied Physics Letters. 1999;75(13):1851-1853.

29. Skolek-Stefaniszyn E, Kaminski J, Sobczak J, Wierzchon T. Modifying the properties of AISI 316L steel by glow discharge assisted low-temperature nitriding and oxynitriding. Vacuum. 2010;85(2):164-169.

30. Wierzchon T, Czarnowska E, Grzonka J, Sowinska A, Tarnowski $\mathrm{M}$, Kaminski J, et al. Glow discharge assisted oxynitriding process of titanium for medical application. Applied Surface Science. 2015;334:74-79.

31. Wu J, Liu H, Li J, Yang X, Hu J. Comparative study of plasma oxynitriding and plasma nitriding for AISI 4140 steel. Journal of Alloys and Compounds. 2016;680:642-645.

32. Liu H, Li J, Chai Y, Wei W, Hu J. Kinetics and enhancement mechanism of plasma oxynitriding for AISI 1045 steel. Surface and Coatings Technology. 2016;302:22-26.

33. Li Y, He Y, Zhang S, Wang W, Zhu Y. Microstructure and corrosion resistance of nitrogen-rich surface layers on AISI 304 stainless steel by rapid nitriding in a hollow cathode discharge. Applied Physics A. 2018;124:65.

34. Li Y, He Y, Wang W, Mao J, Zhang L, Zhu Y, et al. Plasma Nitriding of AISI 304 Stainless Steel in Cathodic and Floating Electric Potential: Influence on Morphology, Chemical Characteristics and Tribological Behavior. Journal of Materials Engineering and Performance. 2018;27(3):948-960.

35. Yu Z, Xu X, Wang L, Qiang J, Hei Z. Structural characteristics of low-temperature plasma-nitrided layers on AISI 304 stainless steel with an a\&apos;-martensite layer. Surface and Coatings Technology. 2002;153(2-3):125-130.

36. Olzon-Dionysio M, de Souza SD, Basso RLO, de Souza S. Application of Mössbauer spectroscopy to the study of corrosion resistance in $\mathrm{NaCl}$ solution of plasma nitrided AISI $316 \mathrm{~L}$ stainless steel. Surface and Coatings Technology. 2008;202(15):36073614.

37. Li CX, Bell T. Corrosion properties of active screen plasma nitrided 316 austenitic stainless steel. Corrosion Science. 2004;46(6):1527-1547.

38. Xu XL, Wang L, Yu ZW, Hei ZK. Microstructural characterization of plasma nitrided austenitic stainless steel. Surface and Coatings Technology. 2000;132(2-3):270-274.

39. Stinville JC, Templier C, Villechaise P, Pichon L. Swelling of $316 \mathrm{~L}$ austenitic stainless steel induced by plasma nitriding. Journal of Materials Science. 2011;46(16):5503-5511. 
40. Borgioli F, Galvanetto E, Bacci T. Influence of surface morphology and roughness on water wetting properties of low temperature nitrided austenitic stainless steels. Materials Characterization. 2014;95:278-284.

41. Stinville JC, Villechaise P, Templier C, Riviere JP, Drouet M. Plasma nitriding of $316 \mathrm{~L}$ austenitic stainless steel: Experimental investigation of fatigue life and surface evolution. Surface and Coatings Technology. 2010;204(12-13):1947-1951.

42. Ahangarani S, Sabour AR, Mahboubi F, Shahrabi T. The influence of active screen plasma nitriding parameters on corrosion behavior of a low-alloy steel. Journal of Alloys and Compounds. 2009;484(1-2):222-229.

43. Riviere JP, Cahoreau M, Meheust P. Chemical bonding of nitrogen in low energy high flux implanted austenitic stainless steel. Journal of Applied Physics. 2002;91(10):6361-6366.

44. Kocijan A, Donik C, Jenko M. Electrochemical and XPS studies of the passive film formed on stainless steels in borate buffer and chloride solutions. Corrosion Science. 2007;49(5):20832098 .

45. Lippitz A, Hübert T. XPS investigations of chromium nitride thin films. Surface and Coatings Technology. 2005;200(14):250-253.
46. Wilhartitz P, Dreer S, Ramminger P. Can oxygen stabilize chromium nitride?-Characterization of high temperature cycled chromium oxynitride. Thin Solid Films. 2004;447-448:289-295.

47. Alves C Jr., da Silva EF, Martinelli AE. Effect of workpiece geometry on the uniformity of nitrided layers. Surface and Coatings Technology. 2001;139(1):1-5.

48. Escalada L, Brühl SP, Simison SN. Microscopic Investigation of Pitting Corrosion in Plasma Nitrided Austenitic Stainless Steel. Practical Metallography. 2014;51(9):689-698.

49. Escalada L, Lutz J, Mändl S, Manova D, Neumann H, Simison S. Corrosion properties of stainless steel $316 \mathrm{~L}$ after energetic nitrogen insertion. Surface and Coatings Technology. 2012;211:76-79.

50. Baba H, Kodama T, Katada Y. Role of nitrogen on the corrosion behavior of austenitic stainless steels. Corrosion Science. 2002;44(10):2393-2407.

51. Zhu XM, Lei MK. Pitting corrosion resistance of high nitrogen f.c.c. phase in plasma source ion nitrided austenitic stainless steel. Surface and Coatings Technology. 2000;131(1-3):400-403.

52. Kuczynska-Wydorska M, Flis J. Corrosion and passivation of low-temperature nitrided AISI 304L and 316L stainless steels in acidified sodium sulphate solution. Corrosion Science. 2008;50(2):523-533. 